Kafkas Üniversitesi Sosyal Bilimler Enstitüsü Dergisi

Kafkas University Journal of the Institute of Social Sciences

Sonbahar Autumn 2019, Sayı Number 24, 605-618

DOI:10.9775/kausbed.2019.055

Gönderim Tarihi: 23.09.2019

Kabul Tarihi: 29.10.2019

ESNAF TEŞKİLATLARINDA ŞİRKETLEŞME SÜRECINDE KILIÇÇI ESNAFININ YENIDEN ÖRGÜTLENMESI

\title{
Reorganisation of Sword Makers in the Corporatisation Process in Guilds
}

\author{
Tolga AKAY
}

Dr. Öğr. Üyesi, Kafkas Üniversitesi

Fen-Edebiyat Fakültesi, Tarih Bölümü

tolga_z@hotmail.com

ORCID ID: 0000-0003-0451-4124

Çalışmanın Türü: Araştırma

$\ddot{O} z$

Sanayi Devrimi, Osmanlı Devleti'nde mevcut ekonomik yapıyı derinden sarsmıştır. Sanayi

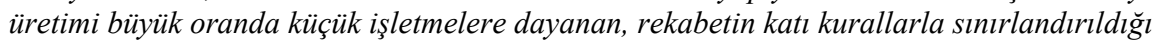
Osmanlı sanayi yapısı kısa sürede çözülmeye başlamıştır. Bu çözülme kapitülasyonlar ve 19. yüzyılda imzalanan ticaret antlaşmalarılyla daha da kötüye gitmiştir. Bu gidişatı değiştirmek için alınan tedbirlerden biri Islah-ı Sanayi Komisyonu'nun kurulmaslyla esnaf örgütlerinin şirketleşme sürecidir. Bozulan esnaf teşkilatlarının bazıları, şirket şeklinde yeniden organize edilerek değişen koşullara adapte edilmeye çalışılmıştır. Bu süreçte yeniden yapılandırılan teşkilatların biri de kılıççı esnafi olmuştur.

Osmanlı klasik çağında önemli bir esnaf grubunu oluşturan kılıç̧̧ esnafi 19. yüzyılda değişen koşullara ayak uyduramayarak dağılmaya yüz tutmuştu. 1870'li yillardan itibaren bu stratejik sanatın tamamen kaybolmaması adına esnaf üyeleri Islah-ı Sanayi Komisyonu vasıtasıyla diğer esnaf kolları gibi devlet desteğini yanlarına alarak yeniden yapılanmayı talep etmişlerdir. Bu makalede 19. yüzyılda yavaş yavaş gözden düşmekte olan bir zanaat kolunun yeniden yapılanma süreci ele alınmıştır.

Anahtar Kelimeler: Sanayii, Esnaf, Islah-ı Sanayi Komisyonu, Kılıç̧̧ Esnafi

Abstract

The Industrial Revolution shook the economic structure deeply in the Ottoman Empire. The Ottoman industry, whose production was significantly based on small sized enterprises and in which hard rules restricted competition, began to be disorganised soon. The capitulations and the commercial treaties signed in the $19^{\text {th }}$ century made this disorganisation worse. One of the measures taken to change this course of events was the corporatisation process of guilds through the establishment of the Commission for the Reformation of Industry (Islah-l Sanayi Komisyonu). Efforts were made to adapt some of the disorganised guilds to the changing conditions by reorganising them as companies. Sword makers were one of the guilds that were reorganised in this process.

Sword makers, which formed one of the important guilds in the classical Ottoman period, had begun to fall apart due to lagging behind the changing conditions of the $19^{\text {th }}$ century. Beginning from the 1870s, members of this guild, like other guilds, demanded to be reorganised with state support through the Commission for the Reformation of Industry in order that this strategic profession is not completely lost. The present article addressed the reorganisation process of a craft that was slowly falling from favour in the $19^{\text {th }}$ century. Keywords: Industry, Guild, Commission for the Reformation of Industry, Sword Makers' Guild 


\section{GİRIŞ}

Sanayi Devrimi sonucu üretim araç ve ilişkilerinin değişmesi Osmanlı sanayisini derinden etkilemiştir. Osmanlı sanayisinin neredeyse tamamen küçük üreticilerden oluştuğu göz önünde bulundurulduğunda bu etkinin tabanda ne kadar derinden hissedildiği anlaşılabilir. Osmanlı esnaf örgütlenmesi, liberal düzende olduğu gibi serbest piyasa ekonomisi ve arztalep dengesi yenine (Barkan, 1985, s. 39) üretim koşullarını ve miktarını belirleme, tüketici ve üreticiyi koruma, haksız rekabeti önleme, eğitim, sosyal yardım vb. bazı işlevleri yerine getiren faydalı bir yapı olarak 19 . yüzyıla kadar varlığını sürdürmeyi başarmıştır. Fakat Sanayi Devrimi’nden sonraki dönem, bu tip kapalı ve rekabet önünde engel teşkil eden yapıların da sonunu getirmiştir. Dolayısıyla Osmanlı sanayi üretimini karşılayan ve birçok sektörde toplanan esnaf örgütlenmesinde, daha önceden iç dinamiklerinden başlayan bozulma çözülmeye dönüşmüştür.

Osmanlı Devleti bu süreçte yüzyıllardır sürdürdüğü ticarette üstünlük anlayışını terk ederek 1838 İngiliz Ticaret Antlaşması ve benzer içerikli, diğer devletlere tanınan ayrıcalıklarla ekonomik bakımdan yabancı istilasına açık bir hale gelmiştir. (Seyitdanlıoğlu 2009, s. 54) 1840 yılında Prusya ile 1834'te kurulan Zollverein'e dâhil devletler adına 1838 Anlaşması'nı esas alan bir anlaşma imzalandı. Bu anlaşma ile ithalat gümrüğü \%5'e düşerken; ihracat gümrüğü ise \% 12'ye yükseltildi. (Önsoy, 1982, s. 6) Bunun sonucunda 1838 'den 1862 y1lına kadar \% 5'in üzerine çıkamayan ithalat vergisinden de anlaşıldığı üzere Osmanlı Devleti, Avrupa'nın pazarı haline gelmiştir. (Yıldırım, 2013, s. 4) Sınırlı üretim yapan Osmanlı küçük üreticisi ise bu durumdan kısa sürede etkilenmeye başladı. (Seyitdanlığlu, 2009, s. 54) Dükkânlar kapanırken, işsizlik artmaya ve devlet de diğer faktörlerin de eklenmesiyle mali olarak zayıflamaya başladı.

Ucuz ve bol üretim yapan Avrupalı üreticiler karşısında Osmanlı küçük üreticisinde ilk darbeyi, Avrupa'da Sanayi Devrimi'nin de kaynağ olan dokumacılık sektörü yemiş, Osmanlı yerel dokumacılığı hızla daralmıştır. Örneğin gelişmiş dokuma merkezlerinden İşkodra'da 1812 y1lında 6000 olan ipek tezgâhı sayısı on y1l içinde 400'e kadar düşmüştür. Tirnova'da ise 1812 yılında 2000 olan dokuma tezgâhı sayısı, 1830'lu yılların başında 200'e kadar gerilemiştir. (Önsoy, 1984, s. 5) Özelde dokumacılık sektöründe başlayan düşüş, yaygınlaşarak devam etmiş hemen tüm sektörler bu süreçten olumsuz etkilenmiştir.

Avrupa'da Sanayi Devrimi'nin en büyük etkilerinden biri esnaftan, 
sanayi ve ticaret burjuvazisi yaratmak olmuştur. En azından değişime ayak uydurabilen esnafın bir kısmı zamanla fabrikatörlere dönüşmüşlerdir. (Eğilmez, 2019, s. 25) Fakat Osmanlı Devleti, beklenen sanayi atılımını gerçekleştiremediği için söz konusu süreçte çözülmeyi engelleyememiştir.

Osmanlı devlet adamları ekonomik çöküşün idrakinde olduğundan sanayiyi güçlendirme çalışmalarına önem vermişlerdir. $\mathrm{Bu}$ amaçla yerli sanayiyi korumak, geliştirmek ve sanayi politikalarını yürütmek üzere bir takım girişimlerde bulunulmuştur. III. Selim ve II. Mahmud dönemlerinde ilk sanayileşme hamleleri kapsamında, devlet sermayesi ile 1804'de Beykoz Kâğıt Fabrikas1, 1812'de Beykoz Deri ve Kundura Fabrikası, 1822'de Paşabahçe Tekel İspirto Fabrikas1, 1827'de Eyüp İplik Fabrikası, 1830'da İslimye Çuha Fabrikası, 1835'de Feshane Fabrikası kurularak ihtiyaçları karşılamaya yönelik atılımlar yapılmıştır. (Clark, 2006, s. 468) 1840'l1 yıllardan 1860'lara kadar da devletçi bir zihniyetle yapılan çalışmalar, ülkenin ihtiyacı olan mamulleri üretecek fabrikalar tesisi veya var olanları modernleştirmek üzerine kurulmuştur. 1843 yılında İzmit Çuha Fabrikası, Çubuklu Billur Fabrikası, 1846'da İzmir Kâğıt Fabrikası, 1852'de Bursa'da İpek İpliği Fabrikası'nın kurulması, Beşiktaş ve Varna'da demir dökümhanelerinin kurulmas1; Hereke Dokuma Fabrikası'nın modernizasyonu bu dönemde sanayinin geliştirilmesi amacıyla atılan adımların başında gelir. (Önsoy, 1984, s. 6)

Avrupa'nın iktisadi etkisi karşısında 1860'lı yıllardan itibaren sanayiyi geliştirmek amacıyla ithal gümrügünün arttırılması, kalifiye eleman ihtiyacının karşılanması için Sanayi Mektebi açılması, Osmanlı ülkesindeki emtianın çeşidinin ve kalitesinin arttırılması adına sergiler açılması, Islah-1 Sanayi Komisyonu'nun kurulması gibi tedbirler hayata geçirilmiştir. (Önsoy, 1984, s. 7-8) Sanayiinin geliştirilme çabalarında, büyük oranda özel sektörün zayıflığı, sermaye yetersizliği, eğitim imkânlarının amaca uygun olmaması gibi sebeplerle yeterli başarı sağlanamamıştır. Bununla birlikte yapılan çalışmaların geniş kapsamlı çabaların bir ürünü olduğu da yadsınamaz. Bu çabalar içerisinde önemli konulardan biri esnaf teşkilatlarında şirketleşme sürecidir.

\section{ESNAF TEŞKILATLARINDA ŞİRKETLEŞME}

Esnaf teşkilatlarının yeniden yapılandırılması hususunda 1860 yılların ortasında oluşturulan Islah-1 Sanayi Komisyonu belirleyici olmuştur. Komisyonun öncelikli görevi, gittikçe küçülen sanayi birimlerini, şirketler halinde yeniden örgütlemekti. Şirketlerin kurulabilmesi için hisse senedi çıkarılarak sağlanacak sermayeyle üretim makineleri satın alınacak ayrıca 
şirketlere ücretsiz arsa tahsisi, vergi muafiyetleri gibi teşvikler sağlanacaktı. (BOA, A.MKT.MHM, 394/28, 24.07.1284; Y1lmaz' 2018, s. 31-32) Öncelikle İstanbul'da uygulanacak program, başarıya ulaştıktan sonra taşrada da uygulanacakt1. (Giz, 1985, s. 1360)

Islah-1 Sanayi Komisyonu'nun çalışmaları neticesinde 1866'da Simkeşhane ve Klabdancı Şirketi, 1868'de Saraçlar Şirketi, 1868'de Kumaşçılar Şirketi, 1868'de Dökmeciler Şirketi, 1869'de Demirciler Şirketi, 1870'de Tabakçılar Şirketi, 1873'de Debbağcılar Şirketi kurulmuştur. (Dinçer, 2016, s. 69-82) Şirketleşme sürecinden beklenen Osmanlı küçük işletmelerinden Avrupa'da olduğu gibi endüstriler yaratılmasıydı.

Şirketler şekil itibarıyla kurulmuş olsalar da, büyük bir itinayla nizamnameleri de hazırlanmakla birlikte özellikle sermayesizlik ${ }^{1}$ ve kötü yönetimler ${ }^{2}$ nedeniyle beklenen verim alınamamıştır. (Avni, 1937, s. 26-27) Kısa ömründe başarılı işlere imza atan Islah-1 Sanayi Komisyonu da 1874 yılında dağıtılmış ve komisyonun görevleri Şûra-yı Devlet Nafia Dairesi'ne havale edilmiştir. (BOA, İ.DH, 687/47945, 09.06.1291.)

Osmanlı Devleti'nde mevcut sanayi yapısının çözülmesi sebebiyle ve Avrupa emtiasıla rekabet amaciyla kurulan bu şirketlerin genel özelliklerine bakıldığında; şirketler özel teşebbüs olarak değil devletin izin ve teşvikiyle kurulmuşlardır. Şirketlerin bazıları Islah-1 Sanayi Komisyonu'nun yönlendirmesiyle kurulurken, bazı şirketlerin kuruluşunda esnafın toplu halde şirketleşme talebi süreci başlatmıştır. (Yılmaz, 2018, s. 33) Bu yöntem farklılığında sektörün önemi ve ihtiyaçlar belirleyici olmuş olmalıdır. Şirketleşme sürecinde sermaye sorunu, hisse senedi çıkarma yoluyla da giderilmeye çalışılmıştır. (Yılmaz, 2018, s. 33) Fakat her zaman için bu yol benimsenmemiştir; zira kılıççı esnafının yeniden yapılanması hazinenin doğrudan sermaye sağlamasıyla mümkün olabilmiştir.

Yeni şirketler, yüzyıllarca serbest rekabet şartlarından uzak esnaf örgütlerinin uzantısı olarak kurulmuşlardır. Dolayısıyla yeni düzende

\footnotetext{
${ }^{1}$ Sermaye sorununa örnek olarak, saraçlar şirketi kurulduktan sonra, şirket mensubu esnaftan bazılarının, sermaye tedariki için eşyalarını satarak aralarında bir miktar para toplayabilmeleri gösterilebilir. Fakat toplanan bu sermayeyle üretilen mamulleri veresiye sattıklarından dolayı üretimde bir süreklilik sağlayamamışlardır. (BOA, İ.HR, 228/13360, 22.06.1284)

2 Kötü yönetimin nedenlerinden biri, eski esnaf üyelerinin şirket yönetmedeki tecrübesizlikleriydi. Örneğin saraçlar şirketi üyelerine, Islah-1 Sanayi Komisyonu tarafindan, ilgili konu üzerine bazı eğitimler verilmiştir fakat bu eğitimlerden pek bir fayda sağlanamamıştır. Bu sebeple şirket üyelerinden birkaçının Avrupa'ya tahsile gönderilmesi fikri gündeme gelmiştir fakat bu düşünce de şirketin geleceği konusunda tereddüt yaşanmasi nedeniyle ertelenmiştir. (BOA, İ.HR, 228/13360, 22.06.1284)
} 
bunlardan rekabet koşulları altında, maliyet analizi yaparak üretim yapmaları beklenemezdi. (Yıldırım, 2013, s. 370) Sonuçta esnaf örgütlerinin şirketleşmesinden, umulan fayda sağlanamamıştır.

\section{KILIÇÇI ESNAFININ "YENIDEN YAPILANMASI"}

1820'li yıllardan I. Dünya Savaşı'na değin, yaklaşık yüz yıl boyunca Batı Avrupa ülkelerinden ithal edilen mamul malların hacmi sürekli genişledi. Bunun sonucunda zanaatlara dayalı üretim faaliyetlerinin bir kısmı rekabet karşısında dayanabilmiş; bazısı gerilemiş, bazıları da tümüyle yıkılıp gitmiştir. (Pamuk, 2010, s. 224) Kılıççı esnafının durumu neredeyse son aşamayı temsil etmekteydi. Bu sebeple kılıççı esnafının yeniden örgütlenme çabası önemlidir.

Kılıççı esnafının yeniden yapılanma süreci, yukarıda belirtilen esnaf teşkilatlarıyla aynı dönemde gerçekleşmekle birlikte bazı yönlerden diğer esnaf teşkilatlarına göre farklılıklar gösterir. Bu farkl11ık, hali hazırda yok olmakla yüz yüze gelen bir sanat kolunun yeniden toparlanma çabasında yatmaktadır. Kılıççı esnafının ürettiği malzeme olan kılıç, 19. yüzyılda, görece ihtiyacı daralan bir mamuldü. $\mathrm{Bu}$ da bazı zorlukları beraberinde getirecektir ki bu zorlukların geçmişi, teşkilatın yeniden yapılanma girişiminden daha eskiye gitmektedir.

Nizam-1 Cedid hareketi ve Yeniçeri Ocağı'nın kaldırılmasından sonra orduda görülen değişim sürecinde, klasik Osmanlı kılıçlarının yerini yavaş yavaş Avrupa tarzı kılıçlar alacaktır. Bu aynı zamanda Osmanlı kılıç üretiminde, Türk tipi eğri kılıç üreten üreticiler için de bir paradigma değişimini ifade eder. İster esnaf tarafindan ister devlet fabrikalarınca üretilsin, eğri kılıç ya da yatağan, gaddare vb. kılıçlar Osmanlı coğrafyasına özgü silahlardı. Bu bakımdan da üretim aşamasında bir yerellik söz konusuydu. Avrupa tipi kılıçların benimsenmesi ise bu alana Avrupalı üreticileri de dâhil etmiş; ulusal pazarı uluslararası pazar haline dönüştürmüştür. Dolayısıyla Osmanlı yönetimi, kılıç tedarikinde yerel kaynaklar yanında ithalata da yönelecekti. Devlet fabrikalarında üretimin yeterli olmadığı durumlarda kılıç, dışarıdan ithal edilecekti. (BOA, ŞD, 2393/36, 07.02.1288)

Kılıççı esnafı için temel zorluk, ithalatın yanında ana kılıç üreticisinin devlet fabrikaları olmasıdı. Tophane-i Âmire ve 1844 'te kurulan Zeytinburnu fabrikası başta olmak üzere, ana üretim merkezleri devlet eliyle kurularak işletilen fabrikalardı.

Üretimde devlet fabrikalarının ön plana çıkması ve Avrupa'dan 
ithalatın artması neticesinde, İstanbul'daki kılıççı esnafının sanatları 1800'lü yılların başından itibaren itibarsız kalmıştır. Bu sebeple II. Mahmud döneminde dağınık halde bulunan kılıççı esnafı, Sultan Ahmet Bimarhanesi binasında toplanarak birleştirilmişti. (BOA, C.AS, 380/15727, 05.12.1246) Kılıççı esnafının tek çatı altında toplanmasıyla üretimlerinde artış ve kılıç fiyatlarında da düşüş beklenirken, bu faaliyetin bir süre esnafın durumunda iyileşme yarattığı anlaşılmaktadır. (BOA, ŞD, 2857/24, 16.02.1288, s. 45)

1859 y1lında ise, Islah-1 Sanayi Komisyonu kurulmadan önce, k1lıç ithalatında görülen zorluklar sebebiyle, sayıları azalan kılıççı esnafının yeni alet edevat tedarikiyle yeniden yapılandırılması fikri ortaya çıkmıştı. Esnafın ürettiği kılıçların Avrupa menşeili emsalleriyle aynı kalitede, daha güzel fakat aynı zamanda pahalı olması, devletin kılıççı esnafı mamullerine ilgi göstermemesine neden olmaktayd1. (BOA, İ.DH, 422/27927, 11.06.1275) Fakat k1lıççı esnafinda bu tarihte yeni bir yapılanma ya da modern araç gereç temini görülmemektedir. Bunun yerine 1860 ' 1 y ylların başından ${ }^{3}$ itibaren kılıç ustaları, dükkânlarındaki faaliyetlerinden alıkonularak Zeytinburnu fabrikasında ${ }^{4}$ yevmiye ile çalıştırılmaya başlanmıştır. Bir nevi angarya usulüyle çalışan ustalar, burada kılıç imali yanında sanayi alayından yanlarına verilen çırakları eğitmişlerdir. $\mathrm{Bu}$ süreçte kendi dükkânlarındaki kazançlarının altında ücretle çalıştırılmışlar ve bu da esnaf üyelerinin sermaye varlıklarında açık bir kötüleşmeye neden olmuştur. Esnaf ustalarına bir müddet sonra ruhsat verilerek sayıları daha önceleri üç yüz civarındayken, elliye kadar düşmüş vaziyette 1868 yılında fabrikadan gönderilmişlerdir. ${ }^{5}$ (BOA, ŞD, 2393/36, 07.02.1288)

31869 tarihli esnafin yeniden organize edilmesi ile ilgili belgede esnafin Zeytinburnu fabrikasında toplanması ile ilgili olarak "10 sene önce" ifadesi geçmektedir. (BOA, ŞD, 2393/36, 07.02.1288) Dolayısıyla esnafın 1859 veya 1860'l yılların hemen başında adı geçen fabrikada istihdam edilmeye başlandığı söylenebilir.

${ }^{4}$ Buras1 1844 yılında kurulan, bir sanayii kompleksini andıran ve "büyük fabrika" (Grande Fabrique) olarak anılan bir nevi sanayii bölgesiydi. Zeytinburnu fabrikasında ordu ve bölgedeki küçük işletmeler tarafından ihtiyaç duyulan demir, çelik ray, kilit, boru, tüfek çakmakları, ustura, bıçak vb. yanında kılıç da üretilmekteydi. Hazine-i Hassa idaresinde olan fabrika, 1848 yılında Tophane-i Âmire'ye devredildi. Devirden sonra fabrika daha çok askeri ihtiyaçlar için üretime ağırlık verdi ise de ihtiyacı karşılamakta genelde yetersiz kaldı. (Y1ldırım, 2016, s. 225; İnal, 2011, s. 738)

${ }^{5}$ Kılıççı esnafi Sultan II. Mahmud döneminden beri İstanbul'da sanatlarını refah içerisinde icra ederken dükkânları terk ettirilerek Zeytinburnu fabrikasına nakl edilmişlerdir. Burada ordu için kılıç ve çeşitli kesici aletler imal eden esnaf ustaları, ileride mükâfat almak ümidiyle yalnız ücretle çalışmaya kanaat etmişlerdir. Daha sonra kılıçlar, fabrikada müstahdem askerler tarafından imal ettirilmeye başlanınca Mayıs 1868 kalfa ve çıraklarının alıkonulmasıyla elli ustadan ibaret bir esnaf heyetine ruhsat verilerek fabrikadan gönderilmişler, sermayesiz ve dükkânsız açıkta bırakılmışlardır. (BOA, ŞD, 2857/24, 16.02.1288, s. 45.) 
Zeytinburnu fabrikasından gönderilmelerine tekabül eden dönemde, kılıççı esnafı gerek Sultan Abdülaziz'e gerekse Babıali'ye sundukları arzuhallerle "bozulan durumlarının eski haline döndürülmesi için" yardım taleplerinde bulunmaya başlamışlardır. Esnaf temsilcilerinin talepleri bir süre görmezden gelinmiştir. Daha sonra Şûra-yı Devlet Maliye Dairesi ile Islah-1 Sanayi Komisyonu'nda iki sene boyunca görüşülmüştür. Nihayetinde 1869 yılında talep dikkate alınmıştır. Komisyondaki müşahedelerden ve esnaf imalatı numunelerin incelenmesiyle (BOA, ŞD, 2857/24, 16.02.1288, s. 20) esnafın işlerinde mahir oldukları anlaşılmıştır. Esnaf temsilcileri Avrupa kılıçlarıyla aynı kalitede ve aynı usulde daha uygun fiyata kılıç yapacaklarını beyan ederek, (BOA, ŞD, 2393/36, 07.02.1288) bir "şirket" tesisi ile kendilerine imtiyaz verilmesi talebinde bulunmuşlardır. (BOA, ŞD, 2857/24, 16.02.1288, s. 9) Kılıççı esnafının talebi, Islah-1 Sanayi Komisyonu'nca makul bulunup desteklenmekle birlikte, Tophane-i Âmire'nin bu girişime pek sıcak bakmadığ 1 anlaşılmaktadır. (BOA, ŞD, 2393/36, 07.02.1288 )

Tophane-i Âmire nazarında esnaftaki temel problem, imal ettikleri numuneler uygun dahi olsa kılıçların eski usullerle yapılmasıydı. Eski usulle imal edilen k1lıçlar ise zaman ve para problemini ortaya çıkarmaktaydı. ${ }^{7}$ Yani Tophane, esnafin uygun fiyata, ordunun kılıç ihtiyacına cevap verebileceği düşüncesinde değildi. Avrupa'dan alınan kılıçlar fabrikalarda muntazam ve mükemmel şekilde üretiliyordu. Eğer Osmanlı kılıççı esnafı da "âdet-i kadimelerini" terk etmek suretiyle Avrupa fabrikalarındaki gibi makineler tedarik ederek, Avrupa kılıçlarının aynısını üretebilirlerse, o zaman esnaf üretimi k1liçlar tercih edilebilirdi. (BOA, ŞD, 2391/1, 30.11.1286) Devletin kılıççı esnafından beklentisi, yeni makine ve usullerle, Avrupa'daki kılıç örnekleri temel alınarak, uygun fiyata ve büyük çapta kılıç

\footnotetext{
${ }^{6}$ Aynı dönemde Harbiye Nezareti'nin Paris'ten 2.149 adet kasaturalı şeşhanenin (adet fiyatı 50 Şilin) satın almasından dolayı kılıççı esnafının mamullerine pek ilgi gösterilmediği görülmektedir. (BOA, ŞD, 2857/24, 16.02.1288, s. 39)

Kılıççı esnafının şirketleşmesi talebinin sürüncemede kalmasının bir nedeni de esnafın ilk başvurusunda, imal ettikleri kılıçların Tophane-i Âmire'ce peşin parayla satın alınması taleplerinin kabul görmemesi ve Asâkir-i Zabitân'ın ise esnafın ürettiği kılıçlara ihtiyaç duymadığının ifade etmesiydi. (BOA, ŞD, 2857/24, 16.02.1288, s. 11)

${ }^{7}$ Tophane-i Âmire'ye göre devlet fabrikalarında uygun kılıçlar imal edilmekteydi fakat esnaf, iktidarsızlığından ve eski usulleri terk etmediklerinden dolayı imal ettikleri kılıçlar kılıçlar hem pahalı hem de muntazam olmamasının yanında emniyetli de değildi. Bu sebeple bu kılıçların esnaftan satın alınması uygun olamazdı. Bunun yanında orduda, özellikle binbaşıdan müşire, zabitan ve mülkiye memurları, kılıçlarını, ücretleri kendileri tarafından ödenmek suretiyle istedikleri yerden yaptırıyorlardı. Bu sebeple kılıççı esnafına münhasır bir kılıç üretimi konusunda Tophane'ce olumlu görüş bildirilmemiştir. (BOA, ŞD, 2857/24, 16.02.1288, s. 34)
} 
imal etmeleriydi. ${ }^{8}$ Fakat esnaf da sermayesizlikten dolayı buna muktedir değildi.

Kılıççı esnafi bu olumsuz bakışa karşın, ordu için belirlenen numuneye uygun; (BOA, ŞD, 2857/24, 16.02.1288, s. 17) Avrupa'dan ithal edilen kılıçların aynılarını daha uygun fiyata imal etmeyi, yeni makineler tedarik ederek yeni usullerle çalışmayı, esnaf üyelerinin kendi taraflarınca imtihan edilerek kabiliyetlerine göre tertip ederek iş bölümünü buna göre düzenlemeyi, "şirketin" itibarını zedeleyecek şekilde uygunsuz kılıç imal edenleri cezalandırmayı (BOA, ŞD, 2857/24, 16.02.1288, s. 20) ve "heyet-i muntazam" şekline girerek yeniden örgütlenmeyi taahhüt etmiştir. Fakat bunların yapılabilmesi için hazineden daha önce diğer bazı esnaf örgütlerine yapılan yardımları da vurgulayarak 100.000 kuruş sermaye talep etmişlerdir. (BOA, ŞD, 2393/36, 07.02.1288) Bu sermaye diğer esnaf örgütlerinin şirketleşmesi sürecinde olduğu gibi hisse senedi çıkarmak şeklinde değil doğrudan hazineden talep edilmiştir. ${ }^{9}$

Dört senede $25^{\prime}$ er bin taksitlerle geri ödenmesi planlanan bu sermayenin tedarikiyle kılıççı esnafi, yeni usulle kurulacak cemiyet ile müdür, kabzımal, yönetim azalarından oluşan bir heyet tarafindan idare edilecekti. (BOA, ŞD, 2393/36, 07.02.1288) Bu paranın alınabilmesi için kefil olan Nişastacılar kethüdası Ali Ağa, aynı zamanda yeni cemiyetin müdür ve kabzımallık görevlerini de üstlenmiştir. Cemiyet idaresi azaları ise birbirlerine kefil olacak muteberândan kılıççı esnafı ustası Osman Ağa ile kılıççılık sanatının ilerlemesi ve ticaretinin geliştirilmesi konusunda istekli olan kılıç ustaları; müdür muavini görevinde Karabet ile Agop, Seyne Kerem ve Bagdasar ustalardan oluşmuştur. (BOA, ŞD, 2393/36, 07.02.1288)

Dağınık halde bulunan dükkânlar, Mahmud Paşa Camii civarındaki kargir mahallin tamir ve düzenlenmesiyle, toplu halde, bir fabrika düzeniyle

\footnotetext{
8 “... kılıç ve sair alat-ı kat'anın Avrupa'dan celbine olan ihtiyaç dahi Avrupa fabrikalarının edevât-ı imaliyesi muntazam ve mükemmel olmak hasebiyle... ... esnaf-ı merkûme dahi âdet-i kadimerini terk ile Avrupa fabrikalarında olduğu gibi makineler celb ve tedarik ile ma 'mulatı Avrupa'dan gönderilenlere tatbik eyledikleri halde oradan kllıç ve sair alat-ı kat' getirilmekten istifna hasıl olacăğ ... (BOA, ŞD, 2391/1, 30.11.1286)

${ }^{9} 100.000$ kuruşluk sermayenin temininde hazine yerine Emniyet Sandığı'na başvurulması esnafa önerilmişse de Emniyet Sandığı'ndan para temini için kefalet yeterli olmayıp, rehin ve faiz uygulaması da mevcuttu. Esnaf temsilcileri bir taraftan gereken alet edevatı satın alacakları diğer taraflardan da borçlarını ödeyerek, sermaye arttırmak durumunda olduklarından rehin bulamayacakları gibi faizi de karşılayamayacaklarını belirterek istedikleri meblağın hazine tarafından verilmesi konusunda 1srarcı olmuşlardır. (BOA, ŞD, 2393/36, 07.02.1288)
} 
birleştirilecekti. Temin edilecek 100.000 kuruş $(1.000 \text { altın })^{10}$ ile de el ile çalışan iki adet destegâh, demirlerin cilasına mahsus iki adet pervaneli kâvsale taşı ve iki adet zımpara çark1 ile iki adet baskı makinesi tedarik edilecekti. (BOA, ŞD, 2393/36, 07.02.1288) ${ }^{11}$

Örgütlenen yeni cemiyetin üreteceğini taahhüt ettiği mamuller ise yalnız devlet için silah olmayıp; vükelâ, yüksek memurlar, gümrük, telgraf, belediye görevlileri ve ahali için uygun kılıçlar, pala, kama, yatağan bıçağı, bıçak, ${ }^{12}$ sungur ve sair kesici aletler, palaska, fişenklik, kılıç kayışı takımları; kâğıt, terzi, berber makasları ile debbağ, aşçı, börekçi, kürkçü, kasap, bakkal, kundurac1, tütüncü dükkânlarında ve hane ile matbahlarda kullanılabilecek bıçak, satır, balta, masat, kerpeten ve bunlara mümasil çeşitli ahna (çapraz) edevatı, demir ve perçin üzerine konulan yaldızdan oluşmaktaydı. (BOA, ŞD, 2393/36, 07.02.1288) $)^{13}$

\begin{tabular}{|c|c|}
\hline Rütbe ve Sınıflara Göre Kılıç Türleri & $\begin{array}{l}\text { Birim } \\
\text { (Kuruş) }\end{array}$ \\
\hline $\begin{array}{l}\text { Asâkir-i Şahane Miralaylarından Ferikân-1 Kirama } \\
\text { kadar (Kınıyla birlikte) }\end{array}$ & 188 \\
\hline $\begin{array}{l}\text { Asâkir-i Bahriye-i Şahane Kol Ağalarından Ferikân-1 } \\
\text { Kirama kadar (Kınıla birlikte) }\end{array}$ & 160 \\
\hline $\begin{array}{l}\text { Asâkir-i Şahane Binbaşılarından Kaymakamlara kadar } \\
\text { (Kınıyla birlikte) }\end{array}$ & 151 \\
\hline $\begin{array}{l}\text { Asâkir-i Şahane Mülazımlarına Kol Ağalarına kadar } \\
\text { (Kınıyla birlikte) }\end{array}$ & 114 \\
\hline Süvari Neferâtına mahsus (Kınıyla birlikte) & 107 \\
\hline Piyade Neferâtına mahsus (Kınıyla birlikte) & 90 \\
\hline
\end{tabular}

Kılıççı esnafının, orduya imal edeceği kılıçlar için taahhüt ettiği fiyatlar ${ }^{14}$. (BOA, ŞD, 2857/24, 16.02.1288, s. 51)

\footnotetext{
${ }^{10}$ Demirci esnafının şirketleşme sürecinde sermayesi 25.000 altın idi. (Yıldırım, 2013, s. 363.) Debbağların ise 10.000 altındı. (Giz, 1985, s. 1361)

${ }^{11}$ El ile kullanılan matkap destegâhı 2 adet: 750/1500 kuruş. Pervaneli kâvsale taşı 2 adet: toplam 6000 kuruş. Zımpara çarkı 2 adet: 1000 kuruş. Demirler için bask1 makinesi 2 adet: 4000 kuruş. Toplam 22500 kuruş tahmini masraf. (BOA, ŞD, 2393/36, 07.02.1288)

${ }^{12}$ Kılıççı esnafının bıçak imal etme talebi, bıçakçı esnafının kethüdasının çağrılarak olurunun alınmasıyla uygun bulunmuştur. Bıçakçı esnafi kethüdası adı geçen bıçakların kılıççı esnafi tarafindan üretilmesinde kendilerince bir mahzur olmadığını beyan etmiştir. (BOA, ŞD, $2857 / 24,16.02 .1288$, s. 3)

${ }^{13}$ Yeni yapının asıl işlevi devlet için kılıç yapımı olmakla birlikte makas, bıçak vb. aletleri imal etmeleri, devletçe kılıç sipariş olunmadığı dönemlerde esnafın boş kalmaması ve sermayeyi tüketmemeleri amacıyla bıçakçı esnafına zarar verilmemek şartıyla kabul edilmiştir. (BOA, ŞD, 2393/36, 07.02.1288)

${ }^{14}$ Kılıç fiyatlarına bazı örnekler: 1774 yılında Tırhala'dan alınan 2.000 kılıç namlusu, birim
} 
Devlet, diğer esnaf örgütlerinin şirketleşmesi ve yeniden yapılanması için sarf edilen mesai ve paranın karşılığının alınamadığ 1 gerekçesiyle çok istekli olmasa $\mathrm{da}^{15}$ esnaf temsilcilerinin talebi, esnafin perişanlıktan kurtarılması, istihdamın artması, üretilecek mamule hem devlet hem de ahali tarafından ihtiyaç duyulması, devlet fabrikalarındaki üretimin kifayet etmediği durumlarda esnaf imalatına ihtiyaç duyulması (BOA, ŞD, $2857 / 24, \quad 16.02 .1288$, s. 3.) ve sanatlarının “...sanayi-i dâhiliyenin mühimlerinden olmast..." (BOA, ŞD, 2857/24, 16.02.1288, s. 20) sebebiyle yeniden canlandırılmasının faydalı olacağı kabul görmüştür ve 1870 yılında esnafa belirlenen maddi yardım yapılmıştır. (BOA, ŞD, 2393/36, $07.02 .1288)^{16}$

Kılıççı esnafı talep ettikleri meblağı almıştır ve bir müdür, kabzımal ile azalardan oluşan bir heyetten müteşekkil olarak yeniden yapılanmıştır ve faaliyet göstereceği sektör de genişlemiştir. Bununla birlikte hisse senedi çıkarılmaması, esnafa, talep etmelerine rağmen stratejik sebeplerle imal ettikleri kılıçlar için tekel mahiyetinde bir imtiyaz verilmemesi; yeniden yapılanmanın bir anonim ya da limited şirket kurulmasıyla sonuçlanmadığını göstermektedir. Aslında yapılan, tükenme noktasına gelen esnafın sermaye aktarımı yoluyla yeniden yapılandırılmasıydı. Fakat bu yapılandırmadan da beklenen iyileşme mümkün olmamıştır.

28 Şubat 1875 tarihli kılıççı esnaf ustalarının dilekçesine göre, esnafa verilen 1000 altın lira, esnafın vekili sarraf elinde bulunmasına karşın, ordu ve diğer devlet daireleri tarafindan 17 ay süresince herhangi bir sipariş verilmemişti. (BOA, ŞD, 2881/23, 16.02.1292) ${ }^{17}$ Esnaf ustaları bu meblağın harcanmasının kılıç imaline bağlı olduğu ve sipariş olmadığından kılıç da

fiyatı: 1,13 kuruş (BOA, C.AS, 281/11671, 21.03.1188); 1805 yılında 33 Nemçekâri demirli kılıç, birim fiyatı: 30 kuruş (ithal), (BOA, C.AS, 904/38981, 23.12.1220). 1829 yılında Asâkir-i Mansûre Ordusu için 1.525 nefer kılıcı, birim fiyatı: 62 kuruş (BOA, C.AS, 542/22699, 27.09.1245); 1842 yılında 3.400 nefer kılıcı, birim fiyatı: 95 kuruş (zabitler için 105 kuruş) (BOA, İ.DH, 68/3400, 06.10.1258); 1843 yılında 525 nefer kılıc1, birim fiyatı: 113 kuruş (BOA, C.AS, 190/8224, 15.07.1259); 1845 y1lında süvari zabiti k1lıcı, birim fiyatı: 75 kuruş, (piyade zabiti için 70 kuruş), (BOA, C.AS, 438/18235, 12.12.1261); 1874 yılında ABD'den ithal 1.000 k1lıç, birim fiyatı: 70 kuruş (BOA, I.DH, 690/48210, 25.08.1291).

15 “... esnaf-ı merkûmenin islah-ı hal ve istihsal-i iktirayı sahihen arzu olunur mevaddan ise de bu makule esnafa şimdiye kadar hazain-i devletten olunan ikrazatdan me'mul ve muntazar olan fevaid hasıl olamadı̆

${ }^{16} 100.000$ kuruş verilirken Nişastacılar Kethüdası Ali Ağa'nın da bu meblağın karşılı̆̆ı emlak ve servet sahibi olması dikkate alınmıştır. (BOA, ŞD, 2393/36, 07.02.1288)

${ }^{17}$ Esnafin başvurusu aşamasında Tophane-i Âmire'ce 40 bin adet yatağan bıçağı ile 6 bin süvari kılıcı sipariş verileceği beyan edilmişti. (BOA, ŞD, 2857/24, 16.02.1288, s. 20) Fakat sermayenin esnafa verilmesinden sonra bu siparişten bir daha söz edilmemiştir. 
imal edilmediği için önce paranın tekrar hazineye iade edilmesini istemişlerdir. Fakat daha sonra devlet dairelerince esnafa kılıç imal ettirilmesiyle ilgili Sultan Abdülaziz'in bir irade-i seniyyesinin çıkması üzerine paranın iadesinden vazgeçmişlerdir. Siparişler gelmeye başlayınca da para, parça parça esnafa dağıtılmaya başlanmıştır. (BOA, ŞD, 2881/23, 16.02.1292) Bundan sonra işler kılıççı esnafi açısından düzelmiş gibi gözükmekle birlikte, 100.000 kuruş da esnafın derdine tam olarak deva olmamıştır.

4 yılda 4 eşit taksitle ödenmesi planlanan ${ }^{18}$ meblağın ilk taksiti olan 25.000 kuruş esnaf tarafından zamanında ödenmiştir. Fakat geri kalan 75.000 kuruştan ödeme zamanı gelen 50.000 kuruş, esnaftan zamanında tahsil edilememiştir. (BOA, ŞD, 2408/5, 06.12.1291) İkinci taksit, kılıç imal aletlerinin tedarikine sarf edildiğinden ödenememiş ve esnaf bu taksitin bir sene tecili için başvuruda bulunmuştur. Esnaf, ellerinde kalan paranın taksit için ödenmesi halinde tanzim işleri için ellerinde para kalmayacağı ve yeni yeni düzene girmeye başlayan durumlarının tamamen çözüleceği gerekçesiyle borcun tecilini talep etmiştir. Aslında sermaye esnafa verilirken, paranın bir kısmı Tophane-i Âmire'nin esnaftan alacağ 1 kılıçlara sayılacaktı, (BOA, ŞD, 2857/24, 16.02.1288, s. 23) dolayısıyla esnafin geri ödemesi de kolaylaşacaktı. Fakat bu durumun ortaya çıkmasından, esnafa yeterli miktarda sipariş verilmediği anlaşılmaktadır. Şûra-yı Devlet, 1874 yılında esnafın talebinin uygun olmadığı ve ikinci taksitin ve geri kalanının zamanı gelince esnaftan ya da kefillerinden tahsil edilmesi yönünde karar vermiştir. (BOA, ŞD, 2408/5, 06.12.1291) Bu kararın verilmesinde hazinenin, olumlu görüş bildirmemesinin etkisi vardır. Hazine, 13 Aralık 1874 tarihli görüşmesinde, yardımlardan sonra, esnaf teşkilatında gözle görünür bir gelişme olmadığı düşüncesindeydi. (BOA, ŞD, 2408/5, $06.12 .1291)$

23 Mart 1875 tarihli esnaf müdür ve kefili olan Ali Ağa'nın bir sonraki dilekçesine göre ise, esnaf bir süre iyi sipariş almış ve külliyetli miktarda kılıç üretimi de planlanmıştı. Bu sebeple Şûra-yı Devlet'te karara bağlandığ 1 üzere ikinci taksit de bir yıl ötelenmiştir. (BOA, ŞD, 2881/44, 29.02.1292) Bununla birlikte devletin üretim ve ithalat politikasında bir

\footnotetext{
${ }^{18}$ İlk ödeme planına göre 100.000 kuruşun 6 senede eğer bu teklif kabul edilmezse 1. ve 2 . taksitini ikişer sene ve 2 . taksitten sonra bâki kalacak meblağın her sene içinde 10 'ar bin kuruş ödenmesiyle 12 senede tamamlanması öngörülmüştü fakat bu plan Maliye Nezareti'nde görüşülecekti. (BOA, ŞD, 2857/24, 16.02.1288, s. 17.) Daha sonra 4 taksit üzerinde uzlaşılmasından Maliye Nezareti tarafından uzun vadeli bu planların kabul edilmediği anlaşılmaktadır.
} 
değişim olmadığından, esnafın durumunda da bir düzelme meydana gelmemiştir. 1888'de kılıççı esnafı, devletin ihtiyaç duyduğu kılıçların devlet fabrikalarında üretilmesi sebebiyle sanatlarına durgunluk geldiği ve zarara uğradıkları gerekçesiyle bir dilekçe vermişlerdir. Esnaf ordunun ihtiyaç duyduğu kılıçların bir kısmının da kendilerince imalini talep ediyordu. (BOA, DH. MKT, 1525/62, 17.11.1305)

Taksitlerin tamamının ödendiği ya da borcun affedildiğine yönelik bir bilgiye ulaşılamamıştır; fakat taksit ödemelerinden bağımsız olarak ithalat politikası ve devletin kılıç üretimi, kılıççı esnafının sonraki süreçte hemen hemen tamamen yok olmasıyla sonuçlanmıştır. Fakat kılıç imal sanatının ortadan kalmasında en temel neden yine askeri teknolojide yaşanan gelişmelerdi.

\section{SONUÇ}

Sanayi Devrimi ve III. Selim'den itibaren askeri alandaki modernleşme hareketleri, Osmanlı ordusuna ve devlet görevlilerine k1lıç imal eden kılıççı esnafını olumsuz etkilemiştir. Orduda modernleşme ile Batı tipi düzenli ordu inşası, silah üretiminde de merkezileşmeyi beraberinde getirmiş; silahlar ağırlıklı olarak devlet fabrikalarında imal edilirken; ithalattan da kaçınılmamıştır. Bu sebeple Osmanlı esnaf teşkilatının içerisinde önemli bir yere sahip kılıççı esnafı da 19. yüzyılda gerilemeye başlamıştır. Yüzyıl ortalarında sanayinin güçlendirilmesi adına atılan adımlar kapsamında kurulan Islah-1 Sanayi Komisyonu ile çözülen esnaf grupları, şirketleşme faaliyetleri altında yeniden yapılandırılmaya başlanmıştır. $\mathrm{Bu}$ yapılandırılma sürecinde kılıççı esnafı da komisyona başvurarak kötüye giden durumlarını düzeltmeye çalışmışlardır.

Kılıççı esnafından müteşekkil yapının farklı dezavantajları vardı. İmal ettikleri malzemenin silah olması, teşekküle stratejik bir önem kazandırıyordu; fakat yine aynı önemden dolayı devlet yalnız bu teşkilata bel bağlayamazdı. Kılıççı esnafının yeniden yapılanma sürecinde talep esnaftan gelmiştir. $O$ yıllarda kılıç ihtiyacının büyük bölümünün daha uygun koşullarda ithalat ve devlet fabrikalarındaki üretimle karşılanıyor olması, devlet açısından kılıççı esnafının şirketleşme zaruretinin hissedilmemesine neden olmuş olmalıdır.

Esnaf teşkilatı sermaye aktarımıyla ve örgüt yapısıyla yeniden yapılandırılmıştır. Bununla birlikte gerek devlet imalathanelerinin üretimi gerekse ithalat, esnafın yeterli sipariş alamamasına ve dolayısıyla da bu girişimin başarısız olmasıyla sonuçlanmıştır. Burada bir diğer dikkat çekici durum, devletin esnaf şirketlerine örneğin Saraçhane esnafinın 
şirketleşmesinde görüldüğü üzere, on iki yıllık imtiyaz, vergi muafiyetleri, saraciye mamullerinin peşin para ile alımı vb. kolaylıkların kılıççı esnafına tanınmamış olmasıdır. Dolayısıyla kılıççı esnafının yeniden yapılanma sürecine tam olarak şirketleşme denilemez. Esnafa bir sermaye aktarımı ile yeniden eski durumlarına kavuşmaları ve yeniden organize olmaları adına bir destek verilmiştir.

Sonuç olarak, kılıççı esnafina verilen destek zamanın koşulları gereği zaten dezavantajlı olan bir sektörde pek de işe yaramamıştır. Eskimeye yüz tutan bir sanat kolunun mensupları, bu sermaye aktarımına rağmen ithalatçı politikaların devamı ve daha da önemlisi bulundukları sektörde, devlet fabrikaları gibi büyük bir rakibin olması sebebiyle yeniden yapılandırma çalışmasından başarıyla çıkamamışlardır. Bu durum kılıççı esnafına özgü değildi; Islah-1 Sanayi Komisyonu'nun şirketleştirdiği birçok esnaf teşkilatı da bu süreçte farklı sebeplerle beklenen başarıyı gösterememişlerdir.

\section{KAYNAKLAR}

Avni, H; Güleryüz H. (1937). Türkiye'de sanayiin inkişafi. İstanbul.

Barkan, Ö. (1985). Osmanlı İmparatorluğu'nda esnaf cemiyetleri. İU İktisat Fakültesi Mecmuasl. C. 41,S. 1-4, 39-46

BOA, A. MKT. MHM, 394/28, 24.07.1284.

BOA, C. AS, $190 / 8224,15.07 .1259$.

BOA, C. AS, 281/11671, 21.03.1188.

BOA, C. AS, 380/15727, 05.12.1246.

BOA, C. AS, 438/18235, 12.12.1261.

BOA, C. AS, 542/22699, 27.09.1245.

BOA, C. AS, 904/38981, 23.12.1220.

BOA, DH. MKT, 1525/62, 17.11.1305.

BOA, İ. DH, 422/27927, 11.06.1275.

BOA, İ. DH, 68/3400, 06.10.1258.

BOA, İ. DH, 687/47945, 09.06.1291.

BOA, İ. DH, 690/48210, 25.08.1291.

BOA, İ. HR, 228/13360, 22.06.1284.

BOA, ŞD, 2391/1, 30.11.1286.

BOA, ŞD, 2393/36, 07.02.1288.

BOA, ŞD, 2408/5, 06.12.1291.

BOA, ŞD, 2857/24, 16.02.1288.

BOA, ŞD, 2881/23, 16.02.1292.

Clark, Edward C. (2006). Osmanlı sanayi devrimi, (Çeviren; Yavuz Cezar), Tanzimat, Değişim Sürecinde Osmanl İmparatorluğu, Halil İnancık, Mehmet Seyitdanlığlu, Ed. İstanbul: Phoenix.

Dinçer, K. (2016). 19. yy Osmanlı esnaf birliklerinin ve mensubu işyerlerinin 
şirketlere ve cemiyetlere dönüşürme denemesi ve sonuçlar, Yayınlanmamış Yüksek Lisans Tezi, İstanbul Üniversitesi SBE. İstanbul.

Eğilmez, M. (2019). Değişim sürecinde Türkiye, Osmanlı'dan Cumhuriyet'e sosyoekonomik bir değerlendirme, (18. Basım), Remzi İstanbul: Kitabevi.

Giz, A. (1985). Islah-1 sanayi komisyonu, Tanzimat'tan Cumhuriyet'e Türkiye Ansiklopedisi. İstanbul: İletişism Yayınları. C. 5, 1360-1362.

İnal, V. (2011). The eighteenth and nineteenth century Ottoman attempts to catch up with Europe, Middle Eastern Studies, 47:5. 725-756.

Önsoy, R. (1982). Türk-Alman iktisadi münasebetleri (1871-1914). İstanbul: Enderun Kitabevi.

Önsoy, R. (1984). Tanzimat dönemi sanayileşme politikası. Hacettepe Üniversitesi Edebiyat Fakültesi Dergisi. C. 2, S. 2, 5-12.

Pamuk, Ş. (2010). Osmanlı-Türkiye iktisadî tarihi 1500-1914 (6. Baskl), İstanbul: İletişim Yayınları.

Seyitdanlığlu, M. (2009). Tanzimat dönemi Osmanlı sanayii (1839-1876), Ankara Üniversitesi Dil ve Tarih-Coğrafya Fakültesi Tarih Araştırmaları Dergisi, C. 28, S. 46, 53-69.

Yıldırım, M. (2013) İstanbul esnafının ölçek ekonomisine geçiş çabaları: "Demirciler şirketi" örneği. Osmanlı İstanbul'u., Feridun M. Emecen, Gürkan, Emrah Safa, Ed. İstanbul: İstanbul Büyükşehir Belediyesi.

Yıldırım, M. (2016). İstanbul'da bir ağır sanayi yatırımı: Zeytinburnu demir fabrikası. İlkçağlardan XXI. Yüzyıla Büyük İstanbul Tarihi, Coşkun Yılmaz Ed. İstanbul: İstanbul Büyükşehir Belediyesi (kültür a.ş.) Yayınları C. VI, 219-225.

Yildırım, M. A. (2013). Dersaadet sanayi mektebi, İstanbul: Kitabevi.

Yıldırım, R. (2010). İstanbul saraçhanesi ve saraç esnafi. Yayınlanmamış Yüksek Lisans Tezi, İÜ SBE, İstanbul.

Yılmaz, Koray R. (2018). Geç kapitalist gelişme bağlamında Osmanlı'da şirketler, Politik Ekonomik Kuram Sosyal Bilimler Dergisi, C. 2, 27-49. 